\title{
Coconut oil as a calibration matrix for headspace gas chromatographic determination of hexanal in edible oils
}

\author{
Vida Vičkačkaitè \\ Gintarè Pipiraitè, \\ Vilius Poškus, \\ Birutė Bugelytė \\ Department of Analytical \\ and Environmental Chemistry, \\ Vilnius University, \\ 24 Naugarduko Street, \\ 03225 Vilnius, Lithuania
}

\begin{abstract}
Oxidation of unsaturated fatty acids of edible oils results in off-flavours, in a decrease in the nutritional properties and in the formation of toxic compounds. Hexanal is a suitable marker of the oxidation process. A new solvent, coconut oil, was suggested for hexanal quantification by static headspace extraction-gas chromatography. Sample equilibration temperature, time, weight and injection time were determined to provide the highest extraction to the headspace efficiency. At the optimized extraction conditions, the hexanal detection limit was $30 \mu \mathrm{g} \mathrm{kg}^{-1}$, linearity was 0.9977 for a concentration range of $50 \mu \mathrm{g} \mathrm{kg}^{-1}-2 \mathrm{~g} \mathrm{~kg}^{-1}$ and repeatability of the results was $1.1 \%$.

The effect of heating on hexanal formation in four edible oils (olive oil, sunflower oil, rapeseed oil and linseed oil) was investigated. The biggest quantity of hexanal was observed in sunflower oil and it significantly increased after heating. Rapeseed oil was the most resistant to the oxidation at elevated temperatures. For linseed oil hexanal is not the most relevant oxidation marker as hexanal is not the main volatile oxidation product.
\end{abstract}

Keywords: edible oils, hexanal, static headspace extraction, gas chromatography

\section{INTRODUCTION}

Edible oils are important components of human diet as they provide energy, are a source of essential fatty acids and other minor but very important constituents, such as sterols, carotenoids, tocopherols and others [1]. However, during storage and especially during heating, unsaturated fatty acids of edible oils undergo oxidation [2, 3]. As a consequence, hydroperoxides are formed. Subsequently they decompose to volatile secondary oxidation products such as alkanes, alkenes, aldehydes, ketones, alcohols, esters, acids and hydrocarbons [2, 4]. Oxidation has a great impact on the quality of food products be-

\footnotetext{
${ }^{*}$ Corresponding author. Email: vida.vickackaite@chf.vu.lt
}

cause of off-flavours, of a decrease in the nutritional properties and especially because of the formation of toxic compounds. Several studies have demonstrated that oxidized oils can be cytotoxic, genotoxic or neurotoxic, can increase propensities to various cardiovascular and metabolic diseases [5-7]. Thus there is a great interest on a fast and simple detection of lipid oxidation.

Numerous studies have demonstrated that the evaluation of the oxidation level can be based on the quantity of secondary oxidation products such as propanal, pentanal, hexanal, heptanal, octaldehyde, nonanal and decanal [4 8-12]. Among the aldehydes, hexanal is often considered the most suitable indicator as it is the main secondary oxidation product of linoleic acid which is one of the principle fatty acids of many edible oils [4, 8, 9, 12, 13,. 
For hexanal determination, headspace sampling combined with gas chromatography is the most frequently used method. Several headspace techniques such as static headspace (SHS), dynamic headspace, headspace solid phase microextraction, headspace sorptive extraction and headspace with trap enrichment can be employed [2, 14, 15. SHS extraction is less sensitive than the headspace techniques that involve a preconcentration of the analytes on a sorbent. On the other hand, its sensitivity is sufficient for determination of hexanal at concentrations that can be considered as an indication of lipid oxidation [4]. In addition, SHS is inexpensive, easy to perform and automate, can successfully be used routinely in control labs thus it is a method of choice for hexanal determination.

The amount of analytes in the headspace depends on the distribution of the analytes between the phases, which in turn depends on the nature of the phases. For quantification, it is necessary to achieve that the distribution of the analyte between the calibration solution and the headspace is the same as between the sample and the headspace. The sample must therefore be dissolved in a solvent that is the same or very similar as the solvent used for calibration solutions.

In the case of SHS extraction of hexanal from edible oils, the oils are not diluted. Calibration solutions of hexanal are usually prepared in fresh corresponding oils or in fresh rapeseed oil [2, 10, 16. However, most of the edible oils contain significant quantities of unsaturated fatty acids, thus the standard solutions prepared in the oils should be kept at low temperature and are of limited storage, otherwise additional quantity of hexanal can form.

In this work, we suggested a new, stable, hexanalfree solvent and developed a sensitive, fast, reliable and reproducible technique for determination of hexanal as an oxidation indicator of edible oils using static headspace extraction coupled to gas chromatography (SHS-GC).

\section{EXPERIMENTAL}

\section{Reagents and samples}

N,N-dimethylformamide (DMF) (99.8\%) was purchased from Roth (Germany), hexanal (98\%) was purchased from Alfa Aesar (Germany). Hexanal stock solutions $\left(10 \mathrm{~g} \mathrm{~kg}^{-1}\right)$ were prepared in DMF, coconut oil and rapeseed oil by weighting. Working hexanal solutions were diluted with a corresponding solvent to a required concentration.

Edible oils (extra virgin olive oil 'La Espanola' (Spain), refined deodorised sunflower oil 'Zolotaja semecka' (Russia), virgin rapeseed oil 'Floriol' (Poland), cold pressed virgin linseed oil (Latvia) and refined coconut oil 'Naturalisimo' (Netherland)) were purchased in a local supermarket.

\section{Instrumentation and conditions}

Headspace gas chromatographic analysis was performed on a PerkinElmer Clarus 580 series gas chromatograph (PerkinElmer, USA) equipped with a flame ionisation detector (temperature $250^{\circ} \mathrm{C}$, hydrogen flow $40 \mathrm{ml} \mathrm{min}^{-1}$, air flow $400 \mathrm{ml} \mathrm{min}^{-1}$,

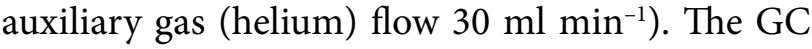
system was equipped with the Elite 200 capillary column $(30 \mathrm{~m} \times 0.25 \mathrm{~mm}$ id, $0.25 \mu \mathrm{m}$ film thickness) (PerkinElmer, USA). Headspace extraction and sample introduction was performed on a PerkinElmer Headspace Sampler Turbomatrix 16 (PerkinElmer, USA) equipped with a balanced pressure system. Twenty millilitre headspace vials were used in all experiments. A headspace vial was positioned in the HS autosampler and equilibrated at selected temperature. The needle temperature and the transition line temperature was by $10^{\circ} \mathrm{C}$ higher than the headspace vial equilibration temperature. The settings of the headspace sampler were $1 \mathrm{~min}$ for pressurization and $0.07 \mathrm{~min}$ for injection. Helium was employed as a carrier gas with 16.7 psi column head pressure. The injector temperature was held at $110^{\circ} \mathrm{C}$. The GC oven temperature was programmed as follows: $40^{\circ} \mathrm{C}$ for $1 \mathrm{~min}$ and from 40 to $250^{\circ} \mathrm{C}$ at $10^{\circ} \mathrm{C} \mathrm{min}^{-1}$.

\section{RESULTS AND DISCUSSION}

\section{Determination of headspace method operating conditions}

For static headspace extraction, sample heating temperature is one of the main parameters to be optimized. Vapour pressure increases with temperature, thus partition of hexanal between a sample phase and a gas phase will decrease and more of the compound will pass into the headspace. Moreover, the time needed to achieve the equilibrium between a sample and a gas phase is significantly reduced at higher temperatures. 
Hexanal content was determined at different equilibration temperatures $\left(90-140^{\circ} \mathrm{C}\right)$, using $1 \mathrm{ml}$ of the solution of hexanal in DMF $\left(1 \mathrm{~g} \mathrm{l}^{-1}\right)$ and keeping equilibration time $10 \mathrm{~min}$. Higher temperatures were not used as for headspace extraction the equilibration temperature should not exceed the boiling point of the solvent, in our case DMF $\left(152^{\circ} \mathrm{C}\right)$. Under these conditions, the content of hexanal in the headspace permanently increased (Fig. 1). On the other hand, a compromise must be found to keep a satisfactory sensitivity of hexanal determination without degrading the oil. As it was mentioned above, hexanal is the main secondary oxidation product of linoleic acid. Sunflower oil contains $65-78 \%$ of linoleic acid [17-19], much more than most of the edible oils. For comparison, the content of linoleic acid in olive oil is 3.5$21 \%$ [19, 20], in rapeseed oil 13.8-30\% [18, 19, 21] and in linseed oil it is $7.6-24 \%[18,21,22]$. Thus sunflower oil is the most suitable for the observation of linoleic acid degradation.

In our previous work, for degradation evaluation, sunflower oil was heated in an open vessel for $10 \mathrm{~min}$ at $90-180^{\circ} \mathrm{C}$ [23] and it was demonstrated that the quantity of hexanal started to increase at $120^{\circ} \mathrm{C}$ temperature. Based on the results, the maximum equilibration temperature that does not generate hexanal formation was considered to be $110^{\circ} \mathrm{C}$.

Selection of a suitable extraction solvent is one of the most important steps in the optimization of hexanal headspace extraction conditions. DMF

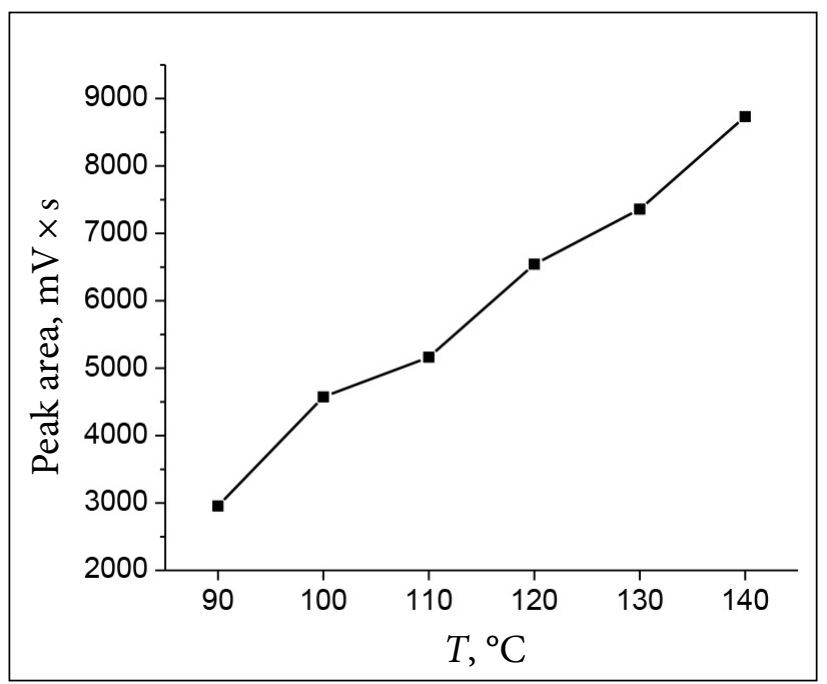

Fig. 1. Influence of the temperature on the hexanal peak area. Hexanal solution in $\operatorname{DMF}\left(1 \mathrm{~g} \mathrm{I}^{-1}\right)$ equilibrated for $10 \mathrm{~min}$ that was initially applied is not the best choice as at the selected $110^{\circ} \mathrm{C}$ temperature a significant quantity of DMF vapour is transferred to the headspace. Because of that hexanal is pushed from the headspace to a solution and its concentration in the headspace decreases.

As it was mentioned above, for hexanal determination in edible oils, calibration solutions are usually prepared in a fresh corresponding oil. Evidently, the oil must be hexanal-free. However, there is a risk of oil oxidation that can result in hexanal formation and thus in the analysis error. In order to prepare standard hexanal solutions with a stable hexanal concentration that does not change for a long time, coconut oil was tested. Because of its high saturated fat content $(>85 \%)$ [24], coconut oil is slow to oxidize.

To evaluate the possible production of hexanal, coconut oil was heated at $180^{\circ} \mathrm{C}$ for $30 \mathrm{~min}$. Then $1 \mathrm{~g}$ was transferred to a headspace vial, equilibrated at $110^{\circ} \mathrm{C}$ for $10 \mathrm{~min}$ and SHS-GC analysis was carried on. The absence of a hexanal peak (at $5.74 \mathrm{~min}$ ) in the chromatogram (Fig. 2) suggests that coconut oil can be used as a solvent for calibration solutions of hexanal.

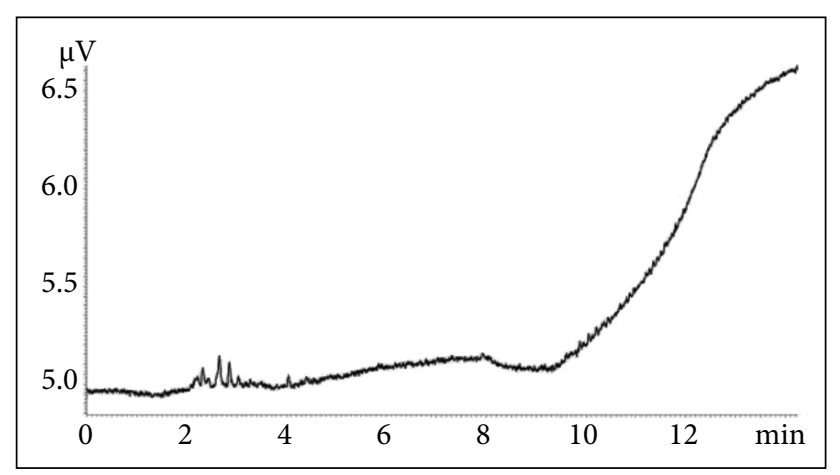

Fig. 2. SHS-GC chromatogram of coconut oil heated at $180^{\circ} \mathrm{C}$ for $30 \mathrm{~min}$. For chromatographic conditions see Experimental

For satisfactory results, transition of hexanal to the headspace from coconut oil should be very close to that from the oil of interest. The release of the volatiles to the headspace depends on the solution viscosity. Viscosities of the studied edible oils increase in the following succession: linseed oil, coconut oil, sunflower oil, olive oil and rapeseed oil [25, 26]. To investigate a suitability of coconut oil as a solvent for calibration solutions of hexanal, hexanal solutions ( 1 and $0.1 \mathrm{~g} \mathrm{~kg}^{-1}$ ) were prepared in coconut oil and in fresh rapeseed oil. Rapeseed 
oil was chosen because of the biggest difference in viscosity among the oils examined compared to coconut oil. $1 \mathrm{~g}$ of each solution was placed into a headspace vial, heated at $110^{\circ} \mathrm{C}$ for $20 \mathrm{~min}$ and subjected for headspace analysis. The analysis was accomplished in triplicate. For the two sets of data of the same concentration of hexanal in coconut oil and in rapeseed oil, $t$ test for differences in means was applied [27]. The $t$ test demonstrated that there was no significant difference between the means of hexanal content in coconut oil and in rapeseed oil for both concentrations indicating that standard solutions of hexanal in coconut oil can be applied for hexanal quantification in other edible oils.

Sample amount has an influence on the analytes concentration in the headspace. Usually, with the increase in sample volume, a concentration of the analyte in the headspace also increases. However, diffusion of the analyte through a thick layer of a viscous sample can require too long equilibration time. It was decided that a reasonable equilibration time should not exceed $30 \mathrm{~min}$. Based on the decision, from 1 to $10 \mathrm{~g}$ of coconut oil containing $1 \mathrm{~g} \mathrm{~kg}^{-1}$ of hexanal was equilibrated at $110^{\circ} \mathrm{C}$ temperature for $30 \mathrm{~min}$. The results demonstrated (Fig. 3) that with the increase of the sample weight, the hexanal peak area initially increased but started to decrease when the sample size exceeded $5 \mathrm{~g}$ indicating that for big samples longer equilibration time is desired.

For the optimisation of equilibration time, 2, 3 and $5 \mathrm{~g}$ of the $0.1 \mathrm{~g} \mathrm{~kg}^{-1}$ solution of hexanal in

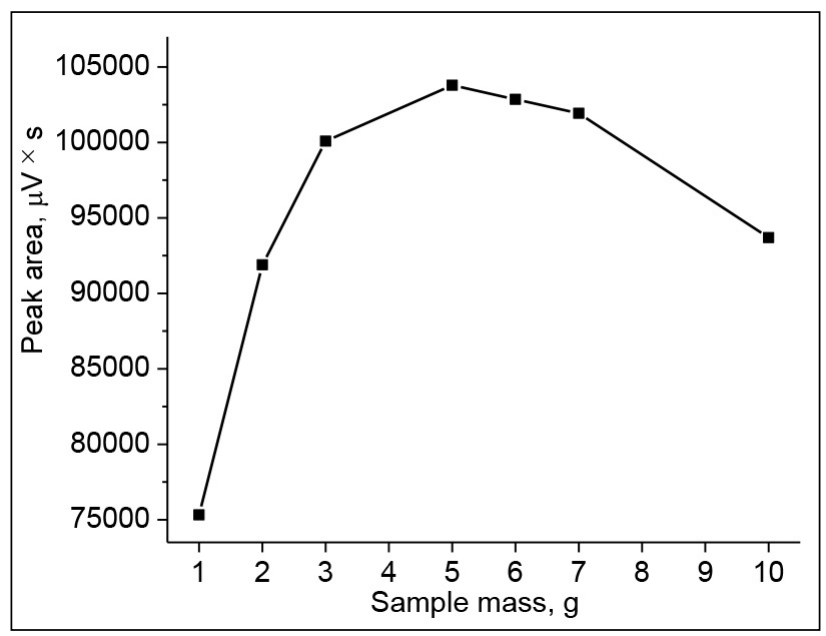

Fig. 3. Influence of coconut sample weight on the hexanal peak area. Hexanal concentration $0.1 \mathrm{~g} \mathrm{~kg}^{-1}$, equilibrated at $110^{\circ} \mathrm{C}$ temperature for $30 \mathrm{~min}$ coconut oil was heated at $110^{\circ} \mathrm{C}$ for $5-30 \mathrm{~min} .1 \mathrm{~g}$ of the sample was not considered because of a significantly lower hexanal concentration in the headspace. The results presented in Fig. 4 demonstrate that for 2 and $3 \mathrm{~g}$ of the sample the GC response has maximized at about $20 \mathrm{~min}$. For the $5 \mathrm{~g}$ sample the GC response did not stabilize even in $30 \mathrm{~min}$. Also, peak areas for 3 and $5 \mathrm{~g}$ samples were quite close. Thus it is reasonable to use $3 \mathrm{~g}$ of the sample for the analysis. The optimum equilibration time was set to $22 \mathrm{~min}$, to allow for possible variations in the heat transfer into the vial.

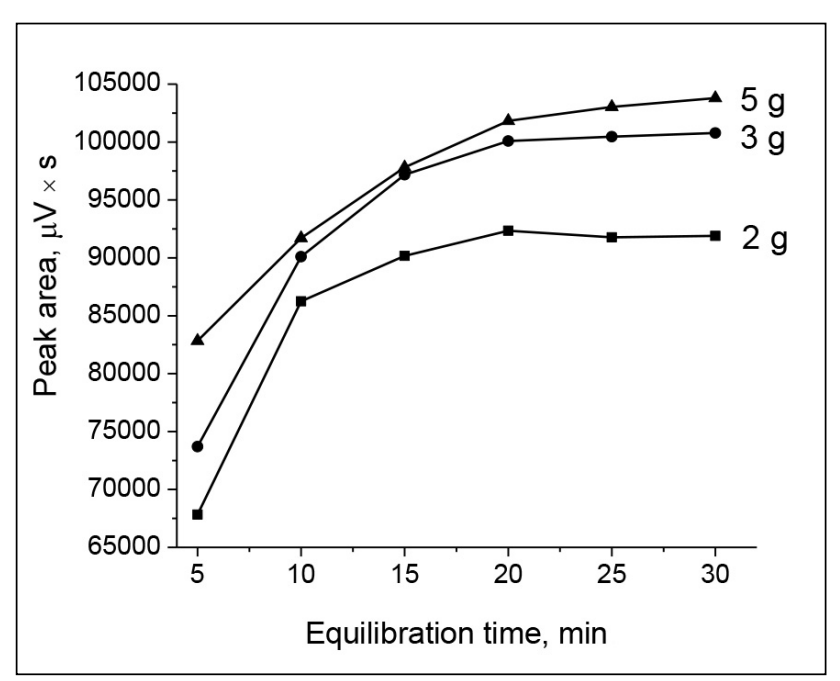

Fig. 4. Influence of coconut sample (2,3 and $5 \mathrm{~g}$ ) equilibration time on the hexanal peak area. Hexanal concentration $0.1 \mathrm{~g} \mathrm{~kg}^{-1}$, equilibrated at $110^{\circ} \mathrm{C}$ temperature

The volume of the gas phase injected to GC has also been optimized. The more gas phase injected, the bigger peak of hexanal should be observed. On the other hand, with the increase of the injected gas phase volume, peaks can start to broaden and tail. The equipment used is supplied by pressure balanced sampling that allows a direct control of the time width of the vapour plug entering the GC column. Injection time widths from 0.01 to $0.2 \mathrm{~min}$ have been examined using the hexanal solution in coconut oil $\left(0.1 \mathrm{~g} \mathrm{~kg}^{-1}\right)$. The results presented in Fig. 5 demonstrate that at low injection times the peak area and the height proportionally increase with the injection time and the efficiency starts to decrease notably when the injection time exceeds $0.1 \mathrm{~min}$. The peak area correlation coefficient is bigger than 0.99 up to 0.09 min injection time. Peak height linearity is more sensitive to 


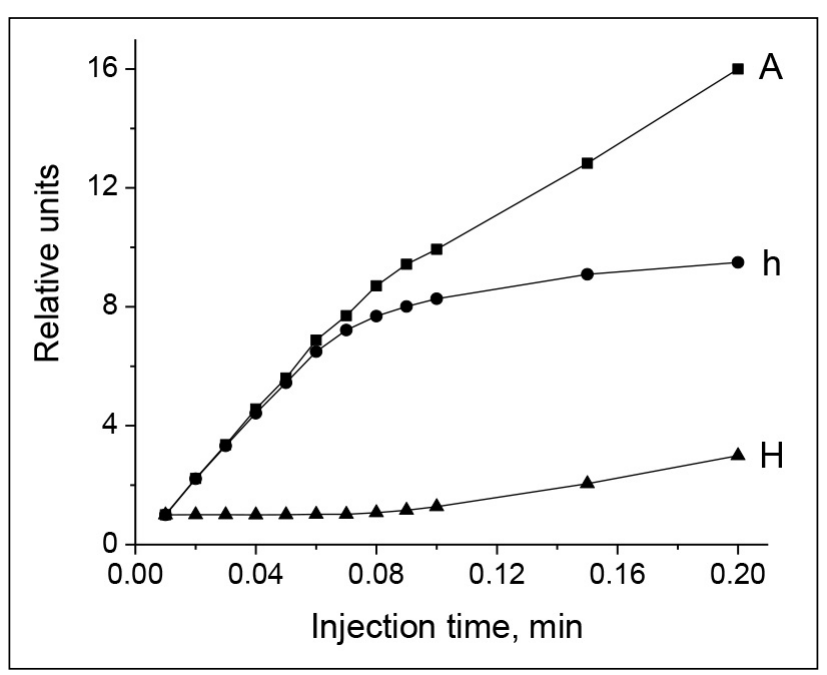

Fig. 5. Relative hexanal peak area (A), height (h), and theoretical plate height $(\mathrm{H})$ dependence on the injection time. The parameters at $0.01 \mathrm{~min}$ are considered equal to 1 . Hexanal concentration $0.1 \mathrm{~g} \mathrm{~kg}^{-1}$, equilibrated at $110^{\circ} \mathrm{C}$ temperature for $22 \mathrm{~min}$

the injection time and at $0.08 \mathrm{~min}$ is less than 0.99 (its value is 0.9859 ). Based on the results, in order to establish the optimal conditions for the maximum recovery of volatile compounds without a loss of efficiency, $0.07 \mathrm{~min}$ injection time was chosen. However, a preliminary SHS-GC analysis of edible oils demonstrated simple chromatograms with a well resolved peak of hexanal. Thus in the case of very low concentrations of hexanal longer injection time can be applied.

Quality parameters were determined under the optimized conditions. The calibration curve was drawn with 8 calibration points with three replicate injections and was linear in the concentration range from $50 \mu \mathrm{g} \mathrm{kg}^{-1}$ to $2 \mathrm{~g} \mathrm{~kg}^{-1}$ with the correlation coefficient 0.9977 . The limit of detection was calculated as three times the baseline noise and was $30 \mu \mathrm{g} \mathrm{kg}^{-1}$. The relative standard deviation was determined by five-replication analysis of the sample with the hexanal concentration $10 \mathrm{mg} \mathrm{kg}^{-1}$ and was $1.1 \%$.

\section{Real sample analysis}

The developed SHS-GC method was applied for hexanal determination in edible oils before and after their heating. Four popular edible oils - olive oil, rapeseed oil, sunflower oil and linseed oil - were analysed untreated, heated at $180^{\circ} \mathrm{C}$ for $10 \mathrm{~min}$, at $200^{\circ} \mathrm{C}$ for $10 \mathrm{~min}$ and at $200^{\circ} \mathrm{C}$ for $30 \mathrm{~min}$. The results presented in the Table demonstrate that the amount of hexanal increases with
Ta ble. Hexanal content in untreated and heated edible oils, $\mathrm{mg} \mathrm{kg}^{-1}$

\begin{tabular}{c|c|c|c|c}
\hline 0il & Untreated & $\begin{array}{c}\mathbf{1 8 0}^{\circ} \mathbf{C}, \\
\mathbf{1 0} \mathbf{~} \mathbf{i n}\end{array}$ & $\begin{array}{c}\mathbf{2 0 0}^{\circ} \mathbf{C}, \\
\mathbf{1 0} \mathbf{~ m i n}\end{array}$ & $\begin{array}{c}\mathbf{2 0 0}^{\circ} \mathbf{C}, \\
\mathbf{3 0} \mathbf{~ m i n}\end{array}$ \\
\hline Sunflower & 3.3 & 20.6 & 31.2 & 36.1 \\
\hline Olive & 3.1 & 7.3 & 26.1 & 26.9 \\
\hline Linseed & 2.6 & 10.5 & 15.8 & 16.2 \\
\hline Rapeseed & 2.5 & 7.7 & 10.7 & 11.3 \\
\hline
\end{tabular}

the heating temperature and time. The biggest quantity of hexanal was observed in sunflower oil and it significantly increased after heating. Rapeseed oil is the most resistant to the oxidation at elevated temperatures. Hexanal peak in the chromatogram of linseed oil was rather small in spite there are data of a higher rate of degradation of linseed oil [21, 28]. This can be explained by the composition of the oils. As it was mentioned above, linseed oil contains a small amount of linoleic acid that is a precursor of hexanal. On the other hand, the main constituent of linseed oil is a-linolenic acid (48-60\%), meanwhile in rapeseed oil its content is about $7 \%$, in olive oil about $1 \%$ and in sunflower oil it is not present at all [29, 30]. The main secondary degradation product of $\alpha$-linolenic acid is 2,4-nonadienal [31]. Its peak is evidenced at $11.9 \mathrm{~min}$ in the chromatogram of linseed oil after heating (Fig. 6).

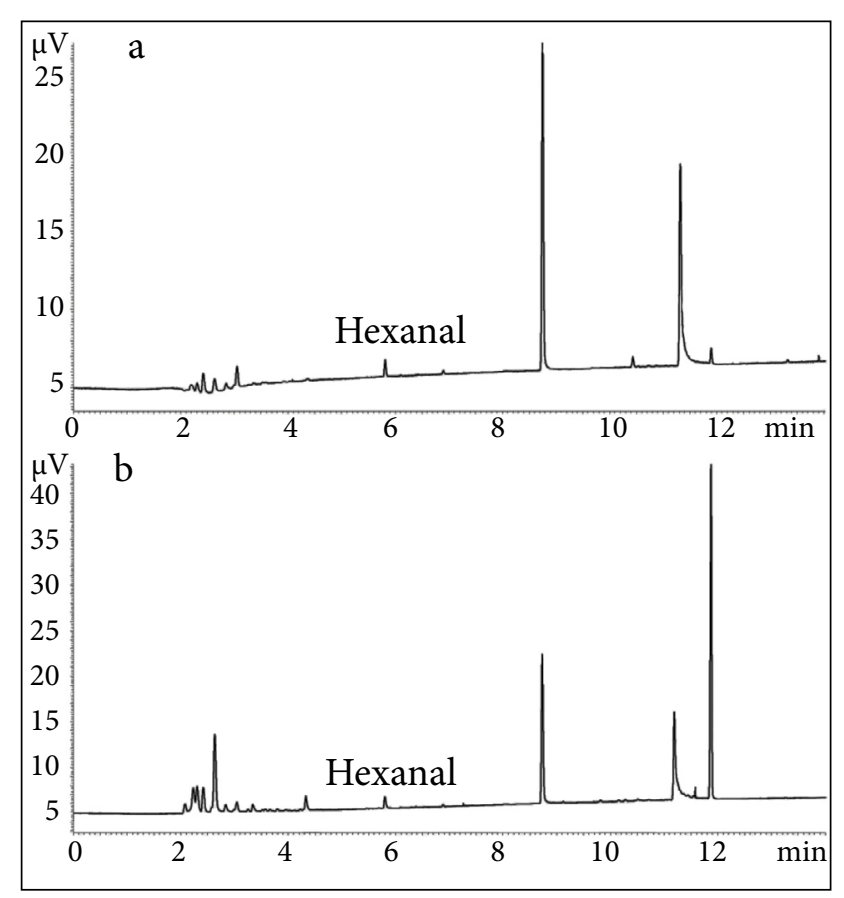

Fig. 6. Chromatograms of untreated (a) and heated at $200^{\circ} \mathrm{C}$ for $10 \mathrm{~min}$ (b) linseed oil. For chromatographic conditions see Experimental 


\section{CONCLUSIONS}

The SHS-GC method for hexanal determination was improved and facilitated by applying coconut oil as a solvent for calibration solutions of hexanal. Before, calibration solutions were usually prepared in fresh corresponding oil. However, most of edible oils contain significant amounts of unsaturated fatty acids that are prone to oxidation with the formation of hexanal that can cause an analysis error. Contrarily, coconut oil mainly consists of saturated fatty acids, is slow to oxidize and thus is a perfect solvent for standard solutions with a stable hexanal concentration that does not change for a long time. At optimized extraction conditions, the sensitivity of the suggested method is quite satisfactory to determine hexanal as a marker of edible oil oxidation. However, for oils containing big amounts of a-linolenic acid (e.g. linseed oil), 2,4-nonadienal should be a more sensitive oxidation marker.

Received 4 June 2020 Accepted 26 June 2020

\section{References}

1. N. L. Puspitasari-Nienaber, M. G. Ferruzzi, S. J. Schwartz, JAOCS, 79, 633 (2002).

2. L. Sghaier, J. Vial, P. Sassiat, et al., Eur. J. Lipid Sci. Technol., 118, 906 (2016).

3. F. Shahidi, P. K. J. P. D. Wanasundara, U. N. Wanasundara, J. Food Lipids, 4, 199 (1997).

4. M. H. Azarbad, H. Jelen, Food Anal. Methods, 8, 1727 (2015).

5. Y. Cui, P. Hao, B. Liu, X. Meng, Food Chem., 233, 77 (2017).

6. N. Gotoh, H. Watanabe, R. Osato, et al., J. Oleo Sci., 54, 397 (2005).

7. F. J. Romero, F. Bosch-Morell, E. J. Jareno, et al., Environ. Health Persp., 106, 1229 (1998).

8. E. Beltran, R. Pla, J. Yuste, M. Mor-Mur, Meat Science, 64, 19 (2003).

9. F. Giuffrida, P. A. Golay, F. Destaillats, et al., Eur. J. Lipid Sci. Technol., 107, 792 (2005).
10. J. Gromadzka, W. Wardencki, Chromatographia, 71, S81 (2010).

11. A. I. Mandic, I. J. Sedej, M. B. Sakac, A. C. Misan, Food Anal. Methods, 6, 61 (2013).

12. S. Panseri, S. Soncin, L. M. Chiesa, P. A. Biondi, Food Chem., 127, 886 (2011).

13. A. Sanches-Silva, A. Rodriguez-Bernaldo de Quiros, J. Lopez-Hernandez, P. Paseiro-Losada, J. Chromatogr. A, 1046, 75 (2004).

14. N. Lorenzo-Parodi, W. Kaziur, N. Stojanovic, et al., TRAC, 113, 321 (2019).

15. A. C. Soria, M. J. Garcia-Sarrio, M. L. Sanz, TRAC, 71, 85 (2015).

16. C. H. Ma, J. J. Ji, C. Tan, et al., Talanta, 120, 94 (2014).

17. E. Ebrahimian, S. M. Seyyedi, A. Bybordi, C. A. Damalas, Agr. Water Manage., 218, 149 (2019).

18. S. P. Singh, D. Singh, Renew. Sust. Energ. Rev., 14, 200 (2010).

19. E. Tvrzicka, L. S. Kremmyda, B. Stankova, A. Zak, Biomed. Pap., 155, 117 (2011).

20. A. Chiou, N. Kalogeropoulos, Compr. Rev. Food Sci. F, 16, 632 (2017).

21. L. Xu, X. Yu, M. Li, et al., Int. J. Food Prop., 20, S2926 (2017).

22. M. Nykter, H. R. Kymalainen, F. Gates, A. M.Sjoberg, Agr. Food Sci., 15, 402 (2006).

23. V. Vičkačkaitè, G. Pipiraitè, V. Poškus, et al., Chemija, 31, 95 (2020).

24. D. A. Ananth, G. Deviram, V. Mahalakshmi, et al., Biocatal. Agric. Biotechnol., 17, 416 (2019).

25. H. Noureddini, B. C. Teoh, L. D. Clements, JAOCS, 69, 1189 (1992).

26. F. Shahidi (ed.), Bailey's Industrial Oil and Fat Products, 6th edn., Wiley-Intersience, New York (2005).

27. D. A. Skoog, D. M. West, F. J. Holler, S. R. Crouch, Fundamentals of Analytical Chemistry, 8th edn., Thomson Learning, Toronto (2004).

28. M. D. Guillen, P. S. Uriarte, Food Control, 28, 59 (2012).

29. P. Gómez-Cortés, J. T. Brenna, P. Lawrence, M. A. De la Fuente, Food Chem., 200, 141 (2016).

30. K. Nuernberg, K. Fischer, G. Nuernberg, et al., Meat Science, 70, 63 (2005).

31. J. Cao, X. G. X. G. Zo, L. Deng, et al., Food Res. Int., 64, 901 (2014). 
Vida Vičkačkaitė, Gintarė Pipiraitė, Vilius Poškus, Birutè Bugelytè

KOKOSŲ ALIEJUS KAIP KALIBRAVIMO

MATRICA HEKSANALIUI NUSTATYTI

MAISTINIUOSE ALIEJUOSE VIRŠERDVĖS DUJŲ CHROMATOGRAFIJOS METODU

Santrauka

Dẻl maistinių aliejų nesočiųjų riebiųjų rūgščių oksidacijos susidaro toksiniai junginiai, prastèja aliejų kvapas ir maistinès savybès. Oksidacijos proceso indikatoriumi gali būti laikomas heksanalis. Heksanaliui nustatyti statinès viršerdvès dujų chromatografijos metodu pasiūlytas naujas tirpiklis - kokosu aliejus. Siekiant užtikrinti geriausią ekstrakcijos ì dujinę fazę efektyvumą, buvo nustatyta méginio termostatavimo temperatūra, termostatavimo trukmè, mėginio kiekis ir méginio įleidimo i chromatografą trukmè. Optimizuotomis ekstrakcijos sąlygomis heksanalio aptikimo riba buvo $30 \mu \mathrm{g} \mathrm{kg}^{-1}$, kalibracinė kreivè tiesinè esant $50 \mu \mathrm{g} \mathrm{kg}^{-1}-2 \mathrm{~g} \mathrm{~kg}^{-1}$ koncentracijai, kalibracinès kreivès koreliacijos koeficiento vertè siekè 0,9977 , o rezultatu pasikartojamumas $-1,1 \%$.

Ištirtas keturių maistinių aliejų (alyvuogių, saulègrąžų, rapsų ir linų sėmenų) kaitinimo poveikis heksanalio susidarymui. Didžiausias heksanalio kiekis nustatytas saulègrąžų aliejuje, jis ypač padidejo kaitinant. Rapsų aliejus kaitinant oksidavosi mažiausiai. Sėmenų aliejui heksanalis nèra pats tinkamiausias oksidacijos žymeklis, nes heksanalis nèra pagrindinis lakus oksidacijos produktas. 